\title{
STUDYING MEDIA IN THE MALAY WORLD: THE SCIENCE OF BUDI AND KABA ${ }^{I}$
}

\author{
Ahmad Murad Merican \\ Universiti Teknologi Petronas, Malaysia
}

\begin{abstract}
This paper employed the field and theme of media studies as a vehicle in exploring the concrete and especially the abstract of the Malay World. It addresses the problems of studying media in the Malay world in the matrix of thought and philosophy. It feeds on how the Malays see themselves and the Others. What is notably absent in the field is questioning its own epistemological assumptions. It isolates itself from the larger Malay cosmology that reflects a poverty of reflexive whispers and voices. The production of knowledge of what passes is accepted as Media Studies is inadequate for comprehending the worlds we inhabit. One approach suggested is to confine it within the evolution of Malay thought and literature, the reality and the metaphor of the Pen, sometimes termed as pekerjaan kalam (the deed of the reed pen), using Vladimir Braginsky's description of what the Malays have inherited. Thus, in citing the pantun and the kaba, the argument of this paper attempts to integrate the genesis of the Malay media to science and philosophy by essentialising the budi manifested through its various avatars - cosmology, epistemology and metaphysics.
\end{abstract}

Keywords: Malay World, media, pantun, kaba, Malay philosophy 


\section{My Tambo $^{2}$ (genealogy) of Experience: Are Media Studies and the Malay World Incompatible?}

The 'Malay World' is a late comer to Media Studies. By way of addressing the problems of studying media in the Malay World, and the Malay World in the matrix of thought and philosophy, I am representing a fragment of the state of media studies that feed on how the Malays see themselves and the Others. Malay consciousness has never been deliberated in this context. In a way, I am addressing approaches and paradigms in which the postcolonial Malay World replicates colonial modes of knowledge production. I have a problem in which my colleagues in Malaysia (and Indonesia) do not seem to have. I am an agnostic of Media Studies, dabbling with thought and tradition.

Perhaps that is what I would like to think in relation to the colleagues of mine whom I am assuming are very territorial people, and I guess would pride themselves as such, short of advocating themselves as 'media studies/communication studies nationalists.' After being involved in the field for more than three decades and having moved through several intellectual routes through the social and human sciences, with an affinity to the history of science and intellectual history, I began to see the larger histories - the epistemological and political constituents and their intersections within social structures. I then arrived at two distinct observations in our constructed imagination of the study of communication and media: one, we cannot assume that media (and communication studies) is exclusive to itself; and two, that there is a lack of fit between media as received knowledge and our existence. Empirically, media studies in the Malay World do not have a conscious focus in terms of context and identity. Media studies, like a number of other disciplines and academic themes such as Malay Studies, still exist in their colonial trappings, and popular discourse. As such it is unable to examine itself as problematic in terms of knowledge production both at the epistemological and popular levels.

Similarly, Malay Studies is compartmentalized based on the study of language, culture and literature while moving itself away from questioning its epistemological assumptions. Media Studies too isolates itself from the larger Malay cosmology, thus reflecting a poverty of reflexive voices, for instance, on the problems of nationalism as a colonial knowledge construct and the interface between nationhood, transnational, technological and globalizing processes. What has 
happened over more than three decades is that media studies have created a totalizing perception of Malaysia and the Malay World and the problems of identity. Categories of relevance and irrelevance are taken for granted ${ }^{3}$. Media Studies, especially in journalism, produce a singular and uniform construct oblivious to the constructs of history and historiography. The topography of journalism and the corpus produced, for example, hardly question historical continuities and ruptures.

For researchers and scholars studying the media in Malaysia and the rest of the Malay World, there is hardly a corpus contextualizing communication, media and journalism within the Malay ethnic and cultural structures. In the first place, studies have not considered the history of languages, oral forms of communication, in particular the pantun and that of the evolution and development of the Malay language, and the diversity of dialects used both in the social and journalistic dimensions. Secondly, Media Studies scholarship could benefit as well as contribute to Malay manuscript studies. As it is now, the study of Malay manuscripts is left to those in the Malay Studies Department. If we look at Malay manuscripts as media and power and as an embodiment of a writing tradition having ramifications on Malay journalism, it would be suggestive of the shortcoming of Media Studies and journalism in Malaysia, as well as on the study of Media in an Asian society. Manuscript studies within the context of media can counter colonial knowledge construction. This leads us to the study of Literature and Malay Literature in particular. Media and journalism studies deny Literature as an integral component for the perceived reasoning that it is not practical and does not contribute to proficiency and professional practice. As such, my fourth observation in this sense is that the corpus on Malay journalism - its theorizing and constitution - would be the eventual loser if Malay identity and its Malay literary tradition are held in abeyance.

This paper addresses then examines and identifies media forms in the larger context of the Malay World's fluidity through the pantun (poem) and journalism in the form of the persuratkhabaran as artifacts.

\section{The Malay World: The Concrete and the Abstract}

There are certainly many understandings and versions as to what constitutes the Malay World. Geographically the 'Malay World' straddles across the Indian and the Pacific Oceans with the Malay Archipelago and the southern part of mainland Asia and part of Indo- 
China as its core. Depending on our vantage point, if we are located in Melaka that is generally associated as the centre of the Malay World to our West, the 'Malay World' stretches from Madagascar (Malagasy) off the coast of Africa in the Indian Ocean, and to the East, to the Easter islands in the far end of the Pacific Ocean off the coast of South America. To the north the 'Malay World' stretches to Taiwan and onto the Hawaiian Islands and in the South to New Zealand.

The Malay World, like much of the non-Western world, had in various degrees encountered with the Occident throughout history, especially over the last 700 years. Post-colonial states in the Malay World such as Malaysia and Indonesia have been under colonial rule where indigenous systems of knowledge, politics and life were replaced. The sacred cosmology - earlier Hindu-Buddhist and later Islam, was transformed into a secular world view where thought and institutions were desacralized. In that regard, geographically, the Malay World's closest neighbor is Australia, a European settler colony that has produced significant scholarship on the Malay world from the various social science and humanities disciplines and academic themes. Australia has also benefitted from some of the foremost thoughts in intellectual production from mainly the Anglo-Saxon world on both sides of the Atlantic. And to its north is the center of the Malay World - the Malay homeland, occasionally labelled as the Nusantara ${ }^{4}$ which geographically means 'pulau-pulau (nusa) di antara (dua tempat yang penting)' islands between two important places (Asmah Haji Omar, 2006, p. 20). The 'two important places' refer to India and China. Therefore, Nusantara means the islands between India and China. To Indonesians, the name Nusantara has long been used from the beginning of nationalist struggles referring to the space - cultural, political and physical that is to be freed from Dutch rule. It is synonymous to the name Indonesia, which means 'the islands of India.'

The Malay World or Alam Melayu covers more than the nationstate of Indonesia, in that it includes Brunei, Malaysia, Singapore and the Philippines. Of late, this region which is in close geographical proximity to that part of the Occident, and more so structured and (dis)oriented by British and Dutch colonialism, is seeing resurgence in interest and identification with Malay identity. The trend, both in Malaysia, and especially in Indonesia (Sakai, 2004) on the revival of 'Malayness' suggests moves representing an outward looking or global approach to ethnicity. In Indonesia, regional autonomy has given greater power to the provinces which is seeing the identity experiencing a revival in the 
various parts of the outer islands. For example, the Minangkabau are beginning to emphasize their identity as Malays. Why this sudden claim to Malay identity? What implications does it have on journalism and media studies?

Despite the plurality of understanding in the historical and contemporary sense ${ }^{5}$, there is a degree of consensus to what constitutes the 'Malay World.' Most academic discussions of 'the Malays' today would conform with the sociologist Geoffrey Benjamin's (2006, in Milner, 2008, p. 5) description of the 'Malay World' - that of encompassing at least "Isthmian Thailand, Peninsular Malaysia, Singapore, the central east coasts of Sumatra, and much of coastal northern, western and southern Borneo, Brunei, parts of Sarawak, and parts of Indonesia Kalimantan." Members of this particular "Malay World' - speaking Malay as a first language and professing Islam would be widely accepted as 'Malay' and, more critically, would think of themselves, as many of us in Malaysia do, as being 'Malay.'

Social scientists' description of the so-called 'Malay proper' often refers to the type of elements in the likes of the kampong lifestyle, the wayang kulit (shadow plays), makyong (traditional theatre), joget dancing, and the bomoh (shaman) as relating to a cultural substratum - a body of knowledge underlying practices and beliefs in Islam which Malays are said to have gradually adopted over six or seven centuries. Milner (2008, p. 8) affirms those as structural features which tend to be identified as characterizing 'Malay' society. But he contrasts these with accounts of Japanese scholars who are often "all the sharper" because of the way they explicitly or implicitly contrast with so-called 'traditional' Japanese society. For example, descent among the 'Malay', it is pointed out, is reckoned bilaterally - through both mother and father; unlike the Japanese case, 'the Malays' "lack the concept of tracing ancestry through a selected line" (Kuchiba, 1974, p. xiii, as cited in Milner, 2008), and seldom remember the names of great-great grandfathers.

However, given the formation of nation states and its consequent process of ideological engineering, the self-definition of Malays in Indonesia, for example, differ from that of the Malays in Malaysia. Assuming that Bangsa Melayu takes on a variety of concepts with notions of community open to redefinition and refashioning, the term bangsa has selectively and precisely conveyed the idea of 'descent' important in the European conceptualization of 'race' (Milner, 2008, p. 235). Given the observations, the 'Malay World' may be thought primarily in a civilizational way - a civilization, referring to states of 
mind and representations, structure and logic (Milner, 2008) and where considering 'the history of Malayness' - beginning in particular with 'the ways of Melaka' (Milner, 2008, p. 242).

\section{Overcoming the Captive Mind: The Budi Paradigm in Studying Media}

The Malay 'Minda' is derived from the English 'mind.' Mind generally refers to an entity that is rational and logical. The Malays usually translate 'mind' to 'minda' in understanding Malay thought about thought itself, the 'Alam Melayu' and the Malay language (Bahasa Melayu). The assumptions of a rational mind are embedded in communication and media scholarship. It assumes that the conception of rationality and logic is similar. For instance, the Malay concept of public opinion is similar to that of a European, or a member of the Occident. The Malays assume that there is only one form of logic and the Media Studies fraternity in the Malay World largely assumes that there is one science and one rationality; and that subconsciously in that sense Europe is universal. It may also occur to us that Europe is unique, but not necessarily universal. The Malay view of periodization in history assumes that all events and ideas have close proximity to the Malay world, so much so that the conventional mode of looking at time, as for example 'middle ages', the 'modern' and the 'post-modern,' or the 'Age of the Enlightenment' or some 'Golden Age' are uncritically accepted.

This is due to the phenomenon of the captive mind. The captive mind $^{6}$ is a victim of Orientalism and Eurocentrism and is characterized by a way of thinking that is dominated by Western thought in an imitative and uncritical manner. Uncritical imitations permeate all levels of scholarly activities and in all fields and disciplines in the human and social sciences, and this includes communication and media studies in the Malay World. The activities affect analysis, abstraction, generalization, problem-setting, conceptualization, description, explanation and interpretation (Alatas, 1972).

Once I was involved in designing a curriculum for Communication and Media Studies in a university across the Strait of Melaka and I was faced with resistance in terms of conceptualization, curriculum philosophy and courses offered. I referred to looking at the epistemology and ontology of communication and media from the inside out, and not only from the outside in. I was attempting to contextualize the curriculum within the history and cosmology of the ethnic group. I 
advocated that kaba and tambo to be structured within the curriculum, and integrating the cultural and literary dimensions. It was opportune to unlearn much of the communication curriculum paradigm established in the several universities in Java.

What had happened to Communication and Media Studies throughout the Malay world over almost 60 years is that the uncritical and imitative mind studying communication and media were at work. The perspectives, histories, paradigms and methodologies come from external sources - external to the Malay world. That is not the issue. The issue is that of a false consciousness of self and identity, the inability to raise original problems and the subconscious dependence thus inducing and perpetuating a Eurocentric view of history and society.

This is where the Cartesian mind cannot be used to comprehend Malay thought. It is an erroneous yardstick that either distorts or conceals the Malay self and media. I would suggest the conceptualization of budi, originating from the Sanskrit buddhi, which means wisdom, understanding, or intellect. Budi can be defined as "the power of forming and retaining conceptions and general notions, intelligence, reason, intellect, mind, discernment, judgement" (Monier-Williams, 1956, p. 733). As part of the Malay jiwa (soul) and vocabulary, its meaning was extended to cover ethics as well as intellect and reason to accommodate Malay culture and thinking.

Budi carries many nuances of meanings in the Malay world view and plays a pivotal role in every aspect of Malay life. It has a complex meaning that cover the areas of goodness, wisdom, decorum, kindness, behavior, morality and service, as in 1. akal, kebijaksanaan; 2. pekerti perangai, akhlak, tingkah laku, kelakuan, watak; 3, sifat baik, perbuatan baik, kebajikan; 4. bicara daya upaya (Kamus Dewan, 2007, p. 212). It can be shown by the phrase akal budi, meaning 'common sense.' It can also mean kindness or virtue, as illustrated in the last two lines of the following pantun:

Pisang emas bawa belayar

Masuk sebiji di bawah peti

Hutang emas boleh dibayar

Hutang budi dibawa mati

(Sail away with a bunch of bananas

One ripe fruit remains on the box

Debts of money we can repay 
Debts of kindness we take to the grave)

Budi also denotes good behaviour' or 'moral character' as in budi pekerti. It can also mean 'discretion' or 'good judgment, when used in conjunction with akal (thought) and hati (feelings) as reflected in budi bicara. According to Lim (2003), when we deal with the 'mind of the Malay' it is the 'budi and its networks' that determines the Malay's thinking (judgement), moral attitudes, and the presentation of an argument.

Budi can also mean the 'mind'. There are two things that be understood from the Malay akal. First, the Malays think with their brains as well as with their hearts (qalbu). Second, the Malay akal does not separate language from culture; it is very much budi-based, hence the term akal budi (Hassan Ahmad, 2010). Studying media within the matrix of modernity or post-modernity for that matter, certainly engages the Malay akal, zeroing on the Malay author who is all at once thinker encompassing the intellectual, the cultural, the philosophical and the metaphysical. In that respect, the emergence of the Malay author who constructs the Malay Grand Narrative is the embodiment of the factual/fiction matrix through the hikayat (epic). The akal, both the conscious and the subconscious attempts to construct a vision of the Malay image and perceptions of the world around him. Hassan identifies them most abundantly in the other Malay texts - the Malay pepatah or proverbs, in the peribahasa, and in the traditional poetic forms of the pantun, the syair, and the gurindam. These are the literary, cultural, intellectual, philosophical and metaphysical text which together express the Malay pandangan hidup or pandangan alam or pandangan sarwa, that is, the Malay world view or weltanschaaung of themselves, the social world and the unseen universe.

Central to all these is the budi. Lim (2003) describes the Malay budi (mind) not as an atomistic component but a molecule. It can be observed but cannot be broken down, as these components are always interconnected and intertwined. Like the Malay author identified by Hassan, we see budi as extending to budiman - the man with all-round budi or one that exists in budi and its networks. The Cartesian mode of thought has demanded of the Malay society and scholar the mode of reason and rationality. Hence, reason and rationality are explicit in theoretical frameworks and methodologies deployed in social inquiry.

It appears that rationality is hidden in the cosmology of the Malay World. That does not mean that its structures and modes of existence are irrational. It only illustrates that the Malay individual and 
the Malay collective also exist on irrational terms, if not another rationality. Overcoming the problems posed by the media phenomenon in the Malay world does not deny the need to re-periodize history, space and time. The man of budiman, or the collective budiman denotes a state of enlightenment, by which if we go by the conventions of historical periodization, it would be the Enlightenment in the Anglo-Saxon world in the $16^{\text {th }}$ century, maintained by the philosophes linked through the network of Paris-London-Edinburgh, which would normally be taken as the one and only 'Enlightenment'.

Enlightenment centred on the akal-budi in the Malay World culminated in Melaka about 1400 to $1511^{8}$. The entity that was Melaka, which induced the narration of the two Malay epics of the Sulalat alSalatin (or the Malay Annals) and the Hikayat Hang Tuah, sometimes called the 'grand Malay epic,' embodied, what Lim (2003, p. 31) describes as "a synthetic connotation between the acuity of reason and the gentleness of feeling, or what we feel through hati." Like the pantun discussed below, both texts, described as philosophical, literary, historical and metaphorical all at once, comprise both a virtual meaning and a concrete meaning. Media Studies in the Malay world ironically has marginalized the category of budi, and its cognates of jiwa, rasa and rupa. The issue of press freedom and the conception of the journalists in certain parts of the Malay world, or within nation states, for example, denotes a different character and soul altogether as compared to that conceptualized by the West.

\section{The Jiwa of the Budi: The Malay Pantun as Message and Medium}

The central concern in this address is the pantun. The pantun is not captured in the radar of Media Studies in the Malay world. Rather its inquiry resides in Malay Studies, of which Malay Literature is a principle component. According to Muhammad Haji Salleh (2006, p. 3), the pantun of the Malay World, in its various names and forms, is found to be indigenous and "unique" and is often considered as a kind of capsule of Malay life, thought and aesthetics. More than any other form, herein is to be found,

The genius of the Malay, his wisdom and wonderful shades of meanings, and modes of expression. For many, including the Malays themselves, here is to be found the 
magic of literature

(Muhammad, 2006, p.

3)

The pantun is essentially an oral form - it was born from an oral past and continued this charmed life essentially as an oral form. However, over time, and with the popularity of the printing presses since the end of the $19^{\text {th }}$ century, collections have been published in many dialects of the language ${ }^{9}$.

The pantun is an ever-developing form. In its earliest meaning the term pantun perhaps did not refer to the form that is divided into two parts of virtuality or foreshadower, as Muhammad describes it and meaning, as we know it today. By the $17^{\text {th }}$ century the word came to stand for the form. In many regions in the Malay World, interestingly, the term essentially meant poetry of the kind to be found among the Malays, especially of the Peninsula and Sumatera, and parts of Borneo. (Muhammad, 2006, p. 13). The Malays' sensitivity to the environment saw the world spread out before them as a teacher, as in the instructive saying - 'alam terkembang jadi guru'.

The earliest pantun forms would probably be two-line verses that have similarities with concise proverbs. They contained a line, the pembayang, that prepared or loosely translated from the Malay term, 'foreshadowed' the music and significance of the lines composing the maksud, or meaning proper. Refer to the following pantun on repaying someone's kindness:

Ada ubi, ada batas.

Ada budi, ada balas

[Tubers in the ridge

Kindness will see repayment]

The two-line verse developed into a four-line form after poets struggling to express themselves noticed that a mere couplet could not do justice to the complex world or the rumination of the serious observer of human life. Thus the four-line pantun was born. The four-line model was perhaps the most successful of other forms ${ }^{10}$, and remains the more elaborate of Malay traditional poetic forms (Hassan, 2010). The four-line pantun has the first two lines of the four-line verse as the foreshadow or meaning indicator (pembayang maksud) rhyming with the words in the last two lines called the meaning stanza or the meaning proper (rangkap 
maksud). What is significant is that the pantun exponent creates the structure orally and spontaneously in flawless language to convey meanings.

It is the work of the Malay left-right brain akal. Hassan theorizes that the pantun is the product of the simultaneous left brain-right brain. The first two lines are the product of the right akal, the product of the emotionally intelligent heart, or the product of the Malay creative imagination, and the last two lines which give the substance or meaning to the pantun are the product of the left akal. The abstract and the concrete emerge all at once. Or we call it the virtual and the real all at the same time. This is the medium of the pantun.

The virtuality and the reality of the Alam Melayu breathe the same air. In delivery the first breath is in the first four words and the second the next four words and so on. Pantun performance as in the wayang kulit (shadow play), dondang saying (literally 'love ballads' from the state of Malacca), dikir barat (a form of choral speaking in the east coast of Malaysia) and the lullaby pantuns as well as the adat pantuns (pantuns related to customs) hold peculiar oral qualities dear to the Malays. It offers space for the kaba and the tambo. It is a vehicle for the transmission of origins, observations, criticisms and news.

Pantuns are also intellectual symbols, full of ruminations on life, laws and regulations. They are the unwritten form of communication - a medium holding in abeyance of our understanding of media. Among the Minangkabaus, Bataks and the Peranakans of Melaka, pantuns have always been in ubiquitous at meetings, ceremonies and other rituals. The pantun is exceptionally important in the narratives and art of narration. It goes back to oral tales like the Hikayat Malim Deman, Hikayat Malim Dewa and Anggun Cik Tunggal. On the other hand, it is also found in oral stories newly collected, but have roots in the distant past. In Riau this verse form is generally scattered throughout the many stories of the 'Nyanyi Panjang' (long narrative songs) of the Aslian groups of Riau, and the kaba in Minangkabau ${ }^{11}$.

Oral literature or communication of the many ethnic groups in the Malay World is facing an uncertain situation. Has the pantun succumbed to the mass media and modes of mass communication? The pantun still stands its ground. Its flexibility of adapting to the environment sees it being carried into new genres and uses. We have seen, read and heard pantuns in advertisement, lyrics of songs, comics, introductory lines on television and radio, in plays and films. I have seen 
a pantun inscribed on a wall of a house on the shores of Lake Maninjau in the Minangkabau heartland.

\section{The Kaba of Persuratkhabaran: Studying Journalism}

At this point, I provide a brief criticism of the state of knowledge on journalism in Malaysia. The present corpus views it exclusively in the context and interest of national polity. Thus far, debates with regard to conceptualizing journalism in Malaysia have been silent on the problems of epistemology and journalism as a form of knowledge, history and criticism in relation to colonial society and the nation-state. Thus, there is 'disconnectedness' on journalism as an idea and an area of research in relation to its practice. Ironically the study of journalism as positioned in what is called communication schools in Malaysia has not found their subject matter. After more than three decades, Journalism has been invariably taught and researched as a practice and a profession with much folk wisdom and 'hearsay,' without much historical understanding, criticism or self-consciousness. The history of journalism and values inherent to it are left to the historical and other forms of social sciences. Thus, knowledge of journalism in its historical and cultural contexts are not legitimized and referred to for the very reason that it is not seen as originating from the media studies domain. Studying journalism within and as a form of media as conventionally understood, has led to its domestication, thus denying it as a genre in historical and political consciousness.

Journalism, as object of study, has been invariably taught and studied as a practice and a profession in an imitative and uncritical manner. There is not much historical understanding, criticism or selfconsciousness. Techniques dominate the day. While the idea is not to produce communication scholars or specialists, still there is a stark absence of the subject matter. Knowledge of journalism is transmitted without its historical and cultural contexts and in this case the conditions inhabiting the Malay World and of the Malay corpus. This explains the absence of work on the origins of Malay journalism.

What is needed is research and further studies (and reflection) on journalism as a cultural, political and social capital. Rarely, if at all, has journalism been conceived as such. Exploring how and why the Malay scribe produces news and opinions and its consumption are crucial. Current understandings of journalism and its (dis)contents rest on an information model of news $(k a b a)$. Equating news with information, 
however, may be unhelpful; for the other side of the debate is equally critical. In the Malay world, an understanding of journalism rests in exploring the tradition of writing, debates and opinions. The premise of research needs to ask the right questions. Taking news as a point of departure is erroneous.

Considering the Peninsula and Singapura as part of the Nusantara region, the first Malay newspaper would be Soerat Kabar Bahasa Melaijoe published in East Java in 1856, that is, 20 years preceding Jawi Peranakan. Subsequently we see the Soerat Chabar Betawi in 1858. The two periodicals were the earliest manifestation of Malay journalism using both the Rumi (Romanized) and Jawi (Arabic) script at the same time. Jawi Peranakan would be the first Malay newspaper in Malaysia however not the first Malay newspaper in the Malay World.

Stretching the history of Malay journalism beyond the boundaries of the Malaysian nation-state, Soerat Kabar Bahasa Melaijoe would be the first Malay newspaper. The comprehension of the history of Malay journalism in Malaysia has always been based on the political identity of the Malays, defined by the Federal Constitution. Such an attitude and perception narrows and marginalizes the Malay identity itself, and that of the epistemological and ontological dimensions of journalism contextualized within Malay literary and writing practices. It erases the meaning of writing as a manifestation of intellectual history that has roots in the Malay literary tradition. An approach toward constructing a history of Malay journalism has to set it within the evolution of Malay literature, the reality and the metaphor of the Pen, sometimes termed as pekerjaan kalam (the deed of the reed pen) as Braginsky (2004, p. 1) describes Literature in his historical survey of Malay literature.

Literary writing tradition forms an invaluable heritage to the identity of the Malays who reside in the Malay Peninsula, Sumatera, several regions in Kalimantan, and a number of islands in the Malay Archipelago. Journalism in the Malay world must be seen as a form of continuity to that literary tradition, initially carved out and stored in stone inscriptions using the alphabet from southern India. Stone inscriptions, as found in various parts of Sumatera and the Peninsula evoke a kind of Innisian echo in that it ramifies power and control - and not only reflecting the collective memory of the community at that time. Nevertheless, early Malay writing tradition reflects oral literature and the beginning of the Hindu-Buddhist literary experience during the first 
century through the middle of the $14^{\text {th }}$ century. Henceforth, the Malay Archipelago underwent through the process of Islamization and subsequently European colonization.

If Bahasa Melayu has been the lingua franca among the various ethnic groups in the archipelago as a vehicle for cultural, religious, and commercial communication, the tradition of writing and literature becomes its medium of communication connecting the peoples within the region and between them and the Arab-Persian-Indian tradition and subsequently to the Occident. The current view states that the emergence of journalism in the Malay Archipelago results from European penetration. Moving beyond the modern historical period, Malay journalism can be seen in the context of continuity before pre-European encounters and a transformation of early Malay literary experience. The domain of Malay letters and Malay journalism are two sides of the same intellectual traditions in the history and experience of the evolution of Malay identity.

The craft of journalism in the Malay Archipelago has gone through various changes based on its functions and roles. If earlier on, it reported on events and happenings and missionary activities, it subsequently became a channel for commerce and business transactions and continued to be a medium for cultural and political expression. Indeed, the Malay debat (debat Melayu) began very early before any newspaper in Malay was published. Abdullah Munsyi was responsible for this 'genre'. In the early $1800 \mathrm{~s}$, Abdullah, from his writings, was considered to be the founder of Malay modernism.

The question we pose is: What is the origin of Malay journalism? What is the identity of Malay journalism? What is journalism to Malay identity and society? How is journalism integral to the Malay writing tradition? And how has that writing tradition created Malay consciousness? What is the subject matter of journalism that informs us about Malay identity, or rather the issue of the identity of Malay journalism? It is indeed beyond this paper to answer all these questions.

Discussions on the history and context of journalism in Malaysia and that of Malay journalism are largely based on the premise of news and its rational and objective values. What then is the 'objective world' of the Malays in the context of journalism? Can the journalism that appeared in the Malay world resulting from initial contacts with Europe be separated from the Malay writing tradition and that of Malayness?

The development of the news genre in the Malay press was a long process. The Malay scribe falls along a continuum of what we call 
opinion-influenced stylistic form to the tawarikh, the writing of history as fact and criticism. The traditional story-teller (tukang cerita) takes a new form. The new journalistic medium, which generally began with Jawi Peranakan in 1876 embodied new genres of writing, namely the news genre (khabar) and the commentary genre (makalah). But the latter genre was the more popular in the days before World War II. Integral to Malay journalism throughtout the years are the following genre: (1) news (berita), (2) news analysis (analisis berita), (3) features (rencana), (4) the leader (lidah pengarang), (5) opinion (pendapat), (6) editorial cartoon (kartun editorial), (7) column (pojok), (8) criticism (kritikan), and (9) essay (esei). Generally, genres (numbered three through nine) are conventionally identified as makalah.

The Malay form of makalah was dominated by criticisms of society as manifested in the works of Eunos Abdullah (of Utusan Melayu) and Syed Shaikh al-Hady (of al-Imam). Here the journalist takes a direct part. His or her attitude to an event is not neutral (objective), but evaluative (subjective). The communicator wants to interpret the event, that is, to give it meaning - especially so in our relationship with them. Self-criticism tends to dominate the trajectory of Malay journalism before the colonial period. The Malay journalist played the role of a social scientist, armed with ideological, cultural and philosophical tools, and harnessing the surat khabar as a weapon for reform. During the period between 1876 and before World War II, Malay journalists saw themselves within the context of Nusantara and the Malay World.

\section{Some Concluding Remarks}

History informs our consciousness and our state of mind within the colonial order and imperialistic arrangements. What has happened to the study of media in the Malay World manifest the deep complicity of academic forms of knowledge with institutions of power? Edward Said in his Orientalism (1978) makes it clear on the mode of operation and the detailed texture of cultural domination of an academic discipline in that, as he argues, constitutes nothing less than a science of imperialism. His analyses in Orientalism force us to the recognition that all knowledge may be contaminated as well as implicated even in its very formal or 'objective' structures. To the extent that all knowledge is produced within institutions of various sorts, there is always a determined relation to the state and to its political practices. 
My purpose is to share and relate the problems of the conceptualization and the construction of Media in the Malay World ${ }^{12}$. I have taken the liberty to examine the persona of the field that we are engaged in to that of the Malay defined. The persona of the Malay World is constrained and that fixed entity, bounded, annexed, territorialized and connected to the centers of empires, has certainly created an impression to scholars who have developed an unobtrusive premised pressured by the powers of the state. The fixed entity and bounded territory fed on the nation-states which in effect dismantled traditional polities. At the same time European systems of governance rose using 'colonial knowledge.'

The challenge to the media scholar and researcher here is to know history - the history of the society being studied. How is that history intertwined with media discourses and journalistic practices? For example, the concept of Malay journalism cannot be divorced from colonial knowledge and identity formation. One cannot study Malay journalism if isolated from Malay nationalism. But at the same time, one cannot remain oblivious to the internalization and utilization of knowledge imported into Malay society as Malay nationalism. Popular knowledge on the Malays was transplanted by the colonialists through such institutions as schools, textbooks and the press. The scholar and researcher of media in the Malay World, who has opted for Malaysia as an empirical focus, must be able to manoeuvre that knowledge in light of how the Malays themselves reorganized that acquired knowledge and used it for specific purposes.

By using social science, Sinha (1997) suggests a research agenda for those wishing to begin creating another tradition. Here scholars studying the media in the Malay World can embark on the following:

1. To question the epistemological status of social science concepts, including those of 'indigenous,' 'native,' 'West,' and 'non-West'.

2. To ground social theory in socio-cultural and political conditions of a locality without necessarily rejecting Western social science.

3. To theorize the global politics of academia with a view to uncovering its role in the perpetuation of a world division of labour in the social sciences, whereby non-western scholars are the collectors of empirical data and Western scholars the theorists. 
4. To recognize multiple centers and sources of social theory, that is, to regard all civilizations as potential sources of social science theorizing.

Malay and Malaysian journalism history, for example, have been chronicled as an extension of the European history and now as part of the American order of freedom and democracy, and for good measure, of responsibility, human rights, and now human dignity. History and our collective consciousness have pulled us to conform to these concepts and categories, and continue to shape our identity and how it is transmitted, understood and internalized by us as 'non-knowing' subject and objects'

For understanding the pantun and the persuratkhabaran, the scholar must internalize the following:

- Orality and literacy in context

- Writing and literary traditions of the past and the present

- Theoretical problems of traditions, ideological medium and genres

- Historical periodization

- Self-awareness and the creative process

- Cultural and political transformations

- Technology - material and non-material

- Consumption

The Malay World presents such a rich and diverse laboratory for media and journalism researchers. We have to bring before us the problematique of crafting a new historiography, a new theory, and a new study of the media. The production of knowledge of what passes as Media Studies is inadequate for comprehending the worlds we inhabit. We have to overcome the crisis of confidence, the crisis of theory and the crisis of method. The nexus between geography and history has created artificial borders on modes of knowing. There is yet to be an interaction amongst scholars from the diverse disciplines, significantly, Philosophy, History, Anthropology, Linguistics, and Media Studies. The Malay World is still terra incognita waiting to be explored and demystified, even for the Malay media scholar himself. The study of the pantun as essentializing the budi manifested as cosmological, cultural, metaphysical, and linguistic has to be integral to the curricula of Media Studies at universities in the Malay World. The pantun is both medium and message. 
I end with a pantun which, as I have alluded earlier. This is the pantun which I saw inscribed on a wall in front of a house at the shores of Lake Maninjau in the Minangkabau heartland.

\author{
Yang kuriak itu kundi \\ Yang merah itu sago \\ Yang baik itu budi \\ Yang indah itu baso \\ The speckled is the spotted \\ The Indian pea is red in form \\ The virtuous is kindness \\ The resplendent is decorum
}

\title{
Endnotes
}

${ }^{1}$ Or khabar. Story, news, information (cerita, khabar/berita, maklumat) on an event; a specific narrative, usually referring to Minangkabau society and culture. A narrative dominated by the pantun genre; a folktale told by a storyteller known as the penglipurlara, at times manifesting a humorous manner in the story and the bard; also advice (nasihat dan teladan) on social problems. Stories of the past, origins, and social criticisms through sayings and proverbs.

${ }^{2}$ Also known as teromba. Stories of the past, also known as babad, hikayat. In the context of Minangkabau society, genealogical tales and tales on origins conceived to be a fusion of facts and myths; sometimes known as teromba; a spectacular view of the culture, the origins of rituals and customs. A form of communication as oral history or historiography, historical writing. See Kamus Dewan, $4^{\text {th }}$ edition (2007) 1673; Mohd. Rosli Saludin (2010) "Falsafah Kehidupan Seni Komunikasi Teromba." Dewan Sastera 40 (5), May: 25-31; and "Kaba dan Tambo sebagai Karya Spektakuler dalam Pembentukan Adat dan Budaya Minangkabau. Retreived from http://bundokanduang.wordpress.com/soo8/03/04kabadan-tamb0-sebagai-karya-spektakuler-dalam-pembentukan-adat-danbudaya-minangkabau.

${ }^{3}$ The fact that the study and conceptualization of media in the Malay World generally originated from the West - Britain, the Netherlands and later the United States, have raised issues of their relevance to the problems in Malay society. Another issue to address is that of colonial 
and postcolonial concerns with the problems of irrelevance of the larger social sciences. For further discussion on the subject of the conceptualization of relevance and irrelevance in the social sciences, see Syed Farid Alatas (1996). The Study of the Social Sciences in Developing Societies: Towards an Adequate Conceptualization of Relevance.' Paper presented at the Asia Pacific Regional Conference of Sociology (APRCS), Philippines Social Science Centre, Quezon City, 28-31 May; and Syed Farid Alatas (2006). Alternative Discourses in Asian Social Science: Responses to Eurocentrism. New Delhi: Sage.

${ }^{4}$ The Javanese world view of the Malay Archipelago

${ }^{5}$ For an encyclopedic and provocative survey of the Malays, see Anthony Milner's (2008). The Malays. West Sussex: Wiley-Blackwell.

${ }^{6}$ The concept of the captive mind was first discussed by Malaysian sociologist, Syed Hussein Alatas (1972 and 1974). It refers to the nature of scholarship in the non-Western world, particularly in relation to Western dominance in the social sciences and the humanities. See Syed Hussein Alatas. 1972. 'The Captive Mind in Development Studies,' International Social Science Journal 34(1): 9-25; and 'The Captive Mind in Creative Development,' International Social Science Journal 36 (4): 691-99.

${ }^{7}$ Pandangan sarwa has been suggested by scholar and Malay language advocate, Professor Awang Sariyan, Holder of the Chair in Malays Studies at Beijing University.

${ }^{8}$ Recent new evidence suggests that Melaka kingdom and empire was established earlier in 1262 and not generally accepted as about 1400 .

${ }^{9}$ Including Malay of the Peninsula, Betawi, Riau, Melaka and Jakarta Peranakan, Minangkabau, Ambonese and Achehnese. There are almost a hundred manuscripts of the pantun collected in the libraries of Jakarta, Leiden, Paris, London, Berlin, mostly of the pantuns from the end of the last century and composed of various collections by scholars from England, Holland and Germany. See Muhammad Haji Salleh (2006), Romance and laughter in the Archipelago: Essays on classical and contemporary poetics in the Malay World. Pulau Pinang: Penerbit Universiti Sains Malaysia, p. 3.

${ }^{10}$ Muhammad explains that the restless poets of the Malay World were never satisfied. They experimented with the basic four-line, eight-twelve syllable poems. Some tried to bend the rules - the syllable-count is not adhered to strictly, letting their lines run to over twelve syllables or less than eight. But they could not surpass the basic quatrain with the eighttwelve syllable-counts. The basic quatrain was simple and melodious, 
with metaphors and allusion. When the four-line pantun becomes a constraint, the lines are increased to six, eight, ten, twelve, and in Minangkabau up to twenty-lines. There is also the linked pantun (pantun berkait). See Muhammad, 2006, pp. 13-21.

${ }^{11}$ Tenas Effendi (1997) and Suryadi (1994), cited in ibid., 29.

${ }^{12}$ See Ahmad Murad Merican (2006).

\section{References}

Ahmad Murad Merican. (2005). Media history: Worldviews and communication futures. Kuala Lumpur: University of Malaya Press.

Ahmad Murad Merican. (2006). Telling tales, print and the extension of man: Malay media studies beginning with Abdullah Munsyi, Syed Shaikh al-Hady and Mahathir Mohamad. Kajian Malaysia, 24(1\&2), 151-169.

Ahmat Adam. (1994). Sejarah dan bibliografi akhbar dan majalah Melayu abad kesembilan belas. Bangi: Penerbit Universiti Kebangsaan Malaysia.

Alatas, Syed Farid (2006). Alternative discourses in Asian social science: Responses to Eurocentrism. New Delhi: Sage.

Alatas, Syed Farid (1996). The study of the social sciences in developing societies: Towards an adequate conceptualization of relevance. Paper presented at the Asia Pacific Regional Conference of Sociology (APRCS), Philippines Social Science Centre, Quezon City, 28-31 May.

Asmah Haji Omar. (2005). Alam dan penyebaran bahasa Melayu. Kuala Lumpur: Dewan Bahasa dan Pustaka.

Braginsky, V. (2004). The heritage of traditional Malay literature. Singapore: Institute of Southeast Asian Studies.

Kaba dan Tambo Sebagai karya Spektakuler dalam Pembentukan Adat dan Budaya Minangkabau. Retrieved from http://bundokanduang.wordpress.com/2008/03/04/kaba-dantambo-sebagai-karya-spektakuler-dalam-pembentukan-adat-danbudaya-minangkabau

Kamus Dewan (4th ed.). (2007). Kuala Lumpur: Dewan Bahasa dan Pustaka.

Lim, K. H. (2003). Budi as the Malay mind. IIAS Newsletter, July, 31. Milner, A. (2008). The Malays. West Sussex: Wiley-Blackwell. 
Mohd. Rosli Saludin. (2010). Falsafah kehidupan seni komunikasi teromba. Dewan Sastera, 40(5), 25-31.

Muhammad Haji Salleh. (2006). Romance and laughter in the Archipelago: Essays on classical and contemporary poetics of the Malay world. Pulau Pinang: Penerbit Universiti Sains Malaysia.

Said, E. W. (1979). Orientalism. New York: Vintage.

Sakai, M. (2004). Reviving 'Malayness'. Retrieved from http://ww.insideindonesia.org/edit78/p17-18_sakai.html

Sinha, V. (1997). Reconceptualizing the social sciences in non-western settings: Challenges and dilemmas. Southeast Asian Journal of Social Science, 25(1), 167-181.

Suryadi. (1993). Dendang pauah: Cerita orang Lubuk Sikaping. Jakarta: Yayasan Obor.

Tenas Effendi. (1997). Bujang tan domang: Nyanyi panjang orang Pelangan. Jakarta: Ecole Francaise d'Extreme Orient, The Toyota Foundation and Yayasan Bentang Budaya.

Wan Mohd Nor Wan Daud \& Muhammad Zaini Uthman. (Eds.). (2010). Knowledge, language, thought and the civilization of Islam: Essays in honor of Syed Muhammad Naquib al-Attas. Skudai: Penerbit Universiti Teknologi Malaysia. 
KATHA - The Official Journal of the Centre for Civilisational Dialogue 